\title{
THE ANTI HRSV ACTIVITY OF Ferula halophila Peşmen AQUEOUS AND METHANOL EXTRACT BY MTT ASSAY
}

\author{
Hasan Hüseyin DOĞAN*, Rüstem DUMAN \\ Selçuk University, Science Faculty, Biology Department, Alaeddin Keykubat Campus, Konya, TURKEY \\ Cite this article as: \\ Doğan H.H. \& Duman R. 2021. The Anti HRSV Activity of Ferula halophila Peşmen Aqueous and Methanol Extract by MTT Assay. Trakya Univ J \\ Nat Sci, 22(1): 43-48, DOI: 10.23902/trkjnat.805545
}

Edited by:

Hatice Korkmaz Güvenmez

*Corresponding Author:

Hasan Hüseyin Doğan

hhuseyindogan@yahoo.com

ORCID iDs of the authors:

H.H.D. orcid.org/0000-0001-8859-0188

R.D. orcid.org/0000-0002-2320-7448

Key words:

Ferula halophila

Methanol and aqueous extract

Cytotoxicity

Antiviral activity

Human respiratory syncytial virus

\begin{abstract}
The trend towards natural products in the world is increasing due to the increased drug resistance of infectious diseases, the high prices for drugs and the difficulty of access. Also, bacterial or viral diseases that are difficult to treat and need a long time for proper treatment cause important infections in people. Since effective drugs could not be developed for most viral infections, it is very important to find natural products against viruses to introduce them to the world of science. The antiviral activities of the aqueous and methanol extract from Ferula halophila Peşmen, an endemic species to Turkey, has been investigated against human respiratory syncytial virus (HRSV, ATCC-VR-26). The cytotoxic and antiviral properties of plant extracts were investigated in HRSV / HEp-2 cell systems, respectively by the colorimetric MTT assay.

In the study, the titer of RSV was used as $100 \mathrm{TCID}_{50}$ (50\% tissue culture infective dose). While MNTC (Maximum non-toxic concentration) of methanol extract was $195.313 \mu \mathrm{g} / \mathrm{mL}$ and $\mathrm{CC}_{50}(50 \%$ cytotoxic concentration) was $4366.22 \mu \mathrm{g} / \mathrm{mL}$, it was determined as $\mathrm{MNTC}=$ $390.625 \mu \mathrm{g} / \mathrm{mL}$ and $\mathrm{CC}_{50}=4366.22$ for aqueous extract. According to the results, methanol extract showed more toxicity than the aqueous extract. The MNTC of Ribavirin used as a positive control was determined as $0.98 \mu \mathrm{g} / \mathrm{mL}$ and $\mathrm{CC}_{50}$ was $110.40 \mu \mathrm{g} / \mathrm{mL}$.

As a result of the study, it was determined that the methanol extract was not effective, whereas the aqueous extract had a significant anti-HRSV activity with the values of $50.69 \mu \mathrm{g} / \mathrm{mLEC}_{50}$ (50\% Effective Concentration) and 97.54 Selectivity Index (SI). The $\mathrm{EC}_{50}$ and SI values of Ribavirin were $2.39 \mu \mathrm{g} / \mathrm{mL}$ and 46.19 , respectively.

According to the results, we can explain the presence of antiviral activity only in the aqueous extract and the absence in the methanol extract by the high toxicity of it and the insolubility of the antiviral compounds in the methanol extract.
\end{abstract}

Özet: Dünyada doğal ürünlere yönelik eğilim, enfeksiyöz hastalıkların ilaç direncindeki artış, yüksek ilaç fiyatları ve erişim zorluğu nedeniyle artmaktadır. Ayrıca, tedavisi zor ve uzun süren bakteriyal veya viral hastalıklar insanlar üzerinde önemli enfeksiyonlara neden olur. Çoğu viral enfeksiyon için etkili bir ilaç geliştirilemediğinden, virüslere karşı doğal ürünlerin bulunması ve bilim dünyasına tanıtılması çok önemlidir. Bu amaçla, Türkiye'ye endemik bir tür olan Ferula halophila Peşmen'den elde edilen su ve metanol ekstrelerinin antiviral aktiviteleri, insan solunum sinsityal virüsüne (HRSV, ATCC-VR-26) karşı araştırılmış̧ır. Çalı̧̧mada, bitki ekstrelerinin sitotoksik ve antiviral özellikleri sırasıyla, HRSV/HEp-2 hücre sistemlerinde kolorimetrik MTT deneyi ile araştırılmıştır. RSV'nin titresi 100 DKID $_{50}$ (\%50 Doku kültürü infektif doz) olarak kullanılmıştır.

Metanol ekstresinin MNTC'u (Maksimum non toksik konsantrasyon) 195,313 $\mu \mathrm{g} / \mathrm{mL}$ ve $\mathrm{CC}_{50}$ 'u (\%50 sitotoksik konsantrasyon) 4366,22 $\mu \mathrm{g} / \mathrm{mL}$, su ekstresinin ise MNTC'u 390,625 $\mu \mathrm{g} / \mathrm{mL}$ ve $\mathrm{CC}_{50} 4366,22$ olarak belirlenmiştir. Sonuçlara göre metanol ekstresi su ekstresinden daha toksik özellik göstermiştir. Kontrol olarak kulllanılan Ribavirinin MNTC $0,98 \mu \mathrm{g} / \mathrm{mL}$ ve $\mathrm{CC}_{50}$ ise $110,40 \mu \mathrm{g} / \mathrm{mL}$ olarak belirlenmiştir. Antiviral çalışma sonucunda metanol ekstresinin etkili olmadığ 1 , buna karşın su ektresinin 50,69 $\mu \mathrm{g} / \mathrm{mL} \mathrm{EC}_{50}$ (\%50 etkili konsantrasyon) ve 97,54 SI (Seçicilik indeksi) değerleri ile önemli bir anti-HRSV aktivitesi olduğu belirlenmiştir. Ribavirinin $\mathrm{EC}_{50}$ ve SI değerleri ise sırasıyla 2,39 ve 46,19 $\mu \mathrm{g} / \mathrm{mL}$ dir. Elde edilen sonuçlara göre sadece su ekstresinde antiviral aktivitenin görülmesi ve metanol ekstresinde antiviral aktivitenin olmayışını, methanol ekstresinin toksitesinin yüksek olması ve antiviral özellikte olan bileşiklerin metanol ekstresinde çözünmemesiyle açıklayabiliriz. 


\section{Introduction}

Respiratory syncytial virus (RSV) is a negativestranded segmentless RNA virus belonging to the genus Pneumovirus of the family Paramyxoviridae (Falsey \& Walsh 2000). RSV is recognized worldwide as one of the leading causes of lower respiratory tract disease in infants and children under the age of 5, and the estimated annual number of human respiratory syncytial virus (HRSV)associated hospitalizations is 3.4 million with at least 66,000 deaths worldwide (Hall et al. 2009, Nair et al. 2010, Lambert et al. 2014).

The virus also causes acute respiratory diseases in the elderly (Collins \& Melero 2011) and can be destructive in individuals with weakened immune systems (Dudas \& Karron 1998). Although most individuals are infected with RSV at an early age of their lifes, susceptibility to recurrent RSV infections continues throughout whole life, also in older ages (Varga \& Braciale 2013). RSV can infect the upper respiratory mucosa and may initially replicate in the nasopharynx. It is likely to spread rapidly to the lower respiratory tract by aspiration of secretions and causes morbidity and mortality mainly with the pathology of the lower respiratory tract. Therefore, the management of RSV infection requires an effective strategy to prevent viral infection of both the upper and the lower respiratory tracts (Collins \& Crowe 2007). No licensed RSV vaccine has yet been developed, although the disease remains a common viral cause of serious respiratory disorders (Durbin \& Karron 2003). Failure to develop specific therapeutic or safe and effective vaccines adversely affects the effort to reduce global mortality and morbidity caused by RSV infections.

Ribavirin (RBV) is known as the only drug approved for treatment of RSV infections, and immunoglobulin preparations are also used for prevention from RSV infections. However, none of these methods is cheap, they are difficult to implement (Kneyber et al. 2000, Pelaez et al. 2009) and all potential RSV vaccines as prophylactic and therapeutic candidates are currently under clinical trials (Lindsay et al. 2015).

The genus Ferula L. (Apiaceae) contains about 170 species generally growing in the arid regions of temperate Eurasia, the Canary Islands and North Africa (Downie et al. 2000). The gene centre of the genus is located in West and Central Asia (Drude 1898). Traditionally, some species of this genus are being used both in "the kitchen" and for "medical treatment". The genus is well known in Turkey and aerial or root parts of some species are used as food and aphrodisiac in some parts of the country (Baytop 1984). The exudates of Ferula assa-foetida L. grown in Iran are traditionally used as aphrodisiac and emmenagogue, in addition to their use in the treatment of some cases such as urinary and gastrointestinal diseases, respiratory infections and epilepsy (Samsam Shariat \& Moattar 1990, Iranshahy \& Iranshahi 2011). Coumarin and sesquiterpene coumarins isolated from members of the genus have been reported to have antiviral activity against various viruses such as influenza A virus (H1N1), human rhinoviruses (HRV), HIV, herpes simplex virus type 1 (HSV-1), and antibacterial, anti-ligaminal, antiinflammatory and anti-tumour activities (Mohamed et al. 2006, Gliszczyńska \& Brodelius 2012, Ghannadi et al. 2014, Duman 2016).

Considering the medical features mentioned above, $F$. halophila Peşmen, an endemic species for Turkey, has been chosen to determine its antiviral effects. Although several studies were performed on antiviral properties of extracts of some species of the genus against various viruses, no study was performed on antiviral effects on RSV. In the present study, we tested, cytotoxic and antiviral effects of methanol and aqueous extracts of $F$. halophila on HRSV cultured in HEP-2 human laryngeal epidermoid carcinoma cell line.

\section{Materials and Methods}

\section{Plant samples}

Ferula halophila samples were collected from the Cihanbeyli-Yavşan Salty area Konya province in Central Anatolia, Turkey, and the collected specimens were identified taxonomically by Dr. Osman TUGAY from Selçuk University, Faculty of Pharmacy. A voucher sample is stored at S.Ü. Kon-Fungarium, Konya/Turkey.

\section{Cell and virus}

Human larynx epidermoid carcinoma cells [HEp-2; ATCC (the American Type Culture Collection) CCL 23] were used to culture human respiratory syncytial virus (HRSV Long strain: ATCC VR-26). Cells were propagated at $37^{\circ} \mathrm{C}$ under $5 \% \mathrm{CO}_{2}$ in Eagle's minimum essential medium (EMEM) supplemented with $10 \%$ foetal bovine serum (FBS, ATCC-30-2020), $10000 \mathrm{U} / \mathrm{mL}$ penicillin, $10 \mathrm{mg} / \mathrm{mL}$ streptomycin, and $25 \mu \mathrm{g} / \mathrm{mL}$ amphotericin B. HRSV is a medium-sized (120-200 nm) enveloped virus that contains a linear negative-sense RNA genome (must be converted to a positive RNA prior to translation). Virus (coded as ATCC-VR-26) was purchased from American Type Culture Collection (ATCC) and reproduced in Virology Laboratory of Science Faculty of Selçuk University. The virus was propagated on a $90 \%$ confluent cell monolayer in EMEM with $1 \%$ FBS and antibiotics as described above. Viral titer was determined by $50 \%$ tissue culture infectious dose $\left(\mathrm{TCID}_{50}\right)$ method and expressed as $\mathrm{TCID}_{50}$ per $0.1 \mathrm{~mL}$ (Kaerber 1964). The virus was stored at $-196^{\circ} \mathrm{C}$ until use.

\section{Preparation of the extracts}

Dried aerial parts (body and leaves) of the plant were used for the experiments. Each $30 \mathrm{~g}$ sample in powder form was placed separately in $400 \mathrm{~mL}$ of methanol and $400 \mathrm{~mL}$ of sterile distilled water and extracted for 1 hour with an ultrasonicator at $45^{\circ} \mathrm{C}$. Plant extracts were filtered through Whatman No: 1 filter paper, and then the solvents used were completely evaporated at $45^{\circ} \mathrm{C}$ under reduced pressure in a rotary evaporator (Heidolph Laboratory 4000, Germany). After evaporation, the plant extracts were lyophilized at $-110^{\circ} \mathrm{C}$ under reduced pressure in the 
lyophilizer (Labconco, USA). Each $1000 \mathrm{mg}$ of the lyophilized extracts were dissolved in $10 \mathrm{~mL}$ of EMEM (serum-free) and stock solutions were prepared at a concentration of $100 \mathrm{mg} / \mathrm{mL}$. The stock solutions were sterilized by a trough in $0.22 \mu \mathrm{m}$ Millipore filter, then stored in $2 \mathrm{~mL}$ tubes and stored at $+4^{\circ} \mathrm{C}$ until use. Ribavirin (RBV, R9644-10 mg, Sigma, USA), a drug approved for the treatment of HRSV infections in humans, was purchased. $10 \mathrm{mg}$ ribavirin was dissolved in $5 \mathrm{~mL}$ of EMEM (serum-free). This $2 \mathrm{mg} / \mathrm{mL}$ stock concentration was filtered in $0.22 \mu \mathrm{m}$ Millipore filter, then they were stored at $-80^{\circ} \mathrm{C}$ or $+4^{\circ} \mathrm{C}$ (When stored at $+4^{\circ} \mathrm{C}$, it was used within 1 week).

\section{Cytotoxicity assay}

The cytotoxic effects of methanol and aqueous extracts of $F$. halophila on HEp-2 cells, and RBV were determined by the ability to reduce Trypan blue dye and Tetrazolium salt (MTT) which was described by Ho et al. (2010). 96-well microtiter plates were used in the experiments. The $1^{\text {st }}$ column was used as Negative control $(\mathrm{Nc})$, the $2^{\text {nd }}$ was used as Cell control $(\mathrm{Cc})$, and serial dilutions according to $\log 2$ base for both extract solutions with a concentration of $100,000 \mu \mathrm{g} / \mathrm{mL}$ were used from 50,000 to $195.313 \mu \mathrm{g} / \mathrm{mL}$. A suspension of HEp-2 at a concentration of $0.625 \times 10^{5}$ cells $/ \mathrm{mL}$ was prepared with the cell growth medium, and $100 \mu \mathrm{L}$ cell suspensions were seeded to all wells of the plate ( 6250 cells/well) except the $1^{\text {st }}$ column and all 3 lower wells of columns 3 12 which was used to check whether the extracts had direct chemical interaction with MTT. After 24 hours of incubation at $37^{\circ} \mathrm{C}$ in $5 \% \mathrm{CO}_{2}$, each $100 \mu \mathrm{g} / \mathrm{mL}$ extracts were added on to wells and the plates were incubated for 48 hours. Then, the MTT assay was performed. Mean OD were read via an ELISA reader (Multiskan EX, Lab systems) at a test wavelength of $570 \mathrm{~nm}$ and a reference wavelength of $630 \mathrm{~nm}$. The mean OD values of the extracts of the same concentration without cells were subtracted from the mean OD of the different extract concentrations in the cell-containing wells.

Maximum non-toxic concentrations (MNTCs) of the extracts were determined by comparing them with the OD of the Cc. These MNTCs were used to determine the antiviral activity of the extracts.

In determining the cytotoxic effects of RBV on HEp2 cells, a solution of RBV was prepared at a concentration of $1,000 \mu \mathrm{g} / \mathrm{mL}$ in EMEM from the stock solution $(2,000 \mu \mathrm{g} / \mathrm{mL})$. Subsequent dilutions (from 500 to $1.95 \mu \mathrm{g} / \mathrm{mL}$ concentrations) were prepared from the base of $\log 2$. Then the same procedure which was used to determine the cytotoxic effects of the extracts was followed for RBV.

\section{Antiviral assay}

The anti-RSV activities of the extracts and RBV were evaluated by the MTT test (Andrighetti-Fröhmer et al. 2003, Shoemaker et al. 2004). A suspension of RSV at 100 tissue culture infective dose (TCID $_{50}$ ) was prepared with maintenance medium (EMEM with $1 \%$ FBS).
Dilutions of the test samples (extracts and RBV) in $2 \times$ MNTCs (MNTCs $=195.313 \mu \mathrm{g} / \mathrm{mL}$ for methanol, 390.625 $\mu \mathrm{g} / \mathrm{mL}$ for aqueous and $0.98 \mu \mathrm{g} / \mathrm{mL}$ for ribavirin) were prepared using maintenance medium. Subsequently, twofold dilutions with maintenance medium were prepared from these dilutions. $2.5 \times 10^{4}$ cells were seeded on the wells and incubated at $37^{\circ} \mathrm{C}$ for 24 hours in a $5 \% \mathrm{CO}_{2}$ incubator. When the cells were confluent, the production medium in the wells was evacuated and each $100 \mu \mathrm{L}$ of RSV suspension (containing 100 TCID $_{50}$ ) and each 100 $\mu \mathrm{L}$ of the extract samples were put in the wells, simultaneously. $100 \mu \mathrm{L}$ of RSV suspension and $100 \mu \mathrm{L}$ of maintenance medium were put into Virus Control (VC) wells. $200 \mu \mathrm{L}$ of maintenance medium was added to the Ccwells. Plates were incubated for 2-5 days (more precisely, until $85-90 \%$ CPE was seen in VC wells) for the development of $\mathrm{CPE}$ at $37^{\circ} \mathrm{C}$ in $5 \% \mathrm{CO}_{2}$. When 85 90\% CPE was observed in VC wells, the solutions were removed in the wells, and an MTT assay was performed. The protection percentages were calculated. The $\mathrm{EC}_{50}$ value, which is defined as the concentration of extract (or RBV) that provides protection in $50 \%$ of the infected cells, was determined and the SI of the extracts (or RBV) was calculated.

\section{Statistical analysis}

Non-linear regression analysis in GraphPad Prism for Windows, version 5.03 (Graph Pad Software Inc., San Diego, CA, USA, 2005) was used to determine the $50 \%$ cytotoxic concentration $\left(\mathrm{CC}_{50}\right)$ and $50 \%$ effective concentration $\left(\mathrm{EC}_{50}\right)$ values. To calculate the percentage of cytotoxicity, the following formula was used, where A represents the Optic Dencity (OD) of the Cc and B represents the OD of the extract-treated cells (Andrighetti-Fröhmer et al. 2003);

$$
\% \text { Cytotoxicity }=\frac{A-B}{A} \times 100
$$

The percentage of cell viability (cytotoxicity) was calculated as absorbance of sample/absorbance of control $\times 100$. The selectivity index (SI) was calculated as $\mathrm{CC}_{50} / \mathrm{EC}_{50}$.

The protection percentages were calculated spectrophotometrically from the formula;

$$
\% \text { Protection }=\frac{A-B}{C-B} \times 100
$$

$\mathrm{A}=$ absorbance of extract (or RBV) dilutions

$\mathrm{B}=$ absorbance of virus

$\mathrm{C}=$ absorbance of $\mathrm{Cc}$

Experiments were done in triplicates.

\section{Results and Discussion}

\section{Virus Titration}

In the titration of RSV in HEp-2 cell culture by the microtitration method, the power of infectiousness was determined as DCID $_{50}=10^{-4.5} / 0.1 \mathrm{~mL}$ at the end of the $5^{\text {th }}$ 
day. The CPEs of the virus in HEp-2 cells, and the appearance of uninfected HEp-2 cells (HEp-2 control) are shown in Figs 1-2.

\section{Cytotoxicity and Antiviral Assay Results}

The cytotoxic effect of the extracts and RBV on Hep2 cells, were evaluated by colorimetric cell viability test. In the experiments, the non-toxic dose of the extracts and RBV on HEp- 2 cells was determined. Then, starting from non-toxic doses, the protection percentages and SI of the extracts and RBV were determined. The MNTCs and $\mathrm{CC}_{50}$ values of the methanol, aqueous extracts, and RBV against HEp-2 cells are shown in Table 1. Methanol extract is more toxic than aqueous extract (Fig. 3). The MNTCs of methanol was $195.313 \mu \mathrm{g} / \mathrm{mL}$, while aqueous was $390.625 \mu \mathrm{g} / \mathrm{mL}$, and for RBV was $0.98 \mu \mathrm{g} / \mathrm{mL}$ (Fig. 4). While methanol extract did not show any activity against RSV, on the contrary, the aqueous extract showed an important antiviral activity. The $\mathrm{EC}_{50}$ value of aqueous extract was $50.69 \mu \mathrm{g} / \mathrm{mL}$, while the SI value was 97.54 (Fig. 5). The $\mathrm{EC}_{50}$ and SI values of RBV were $2.39 \mu \mathrm{g} / \mathrm{mL}$ and $46.19 \mu \mathrm{g} / \mathrm{mL}$, respectively (Fig. 6).

In this study, the aqueous extract is even more effective than the standard drug RBV, whereas methanol extract was found to be ineffective against RSV.

Furthermore, it can be seen that the extracts are less toxic than RBV on HEp-2 cells, and $\mathrm{CC}_{50}$ values of aqueous extract and $\mathrm{RBV}$ are higher than $\mathrm{EC}_{50}$ values.

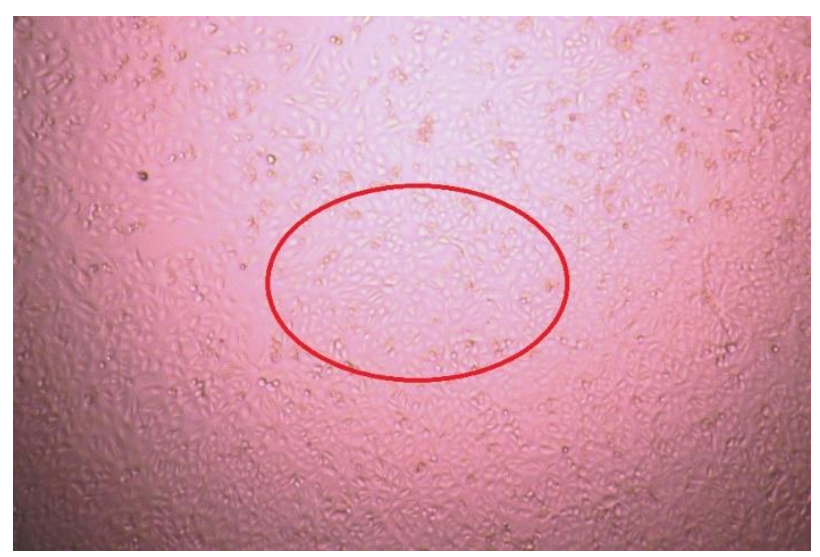

Fig. 1. View of HEp-2 cells (Original).

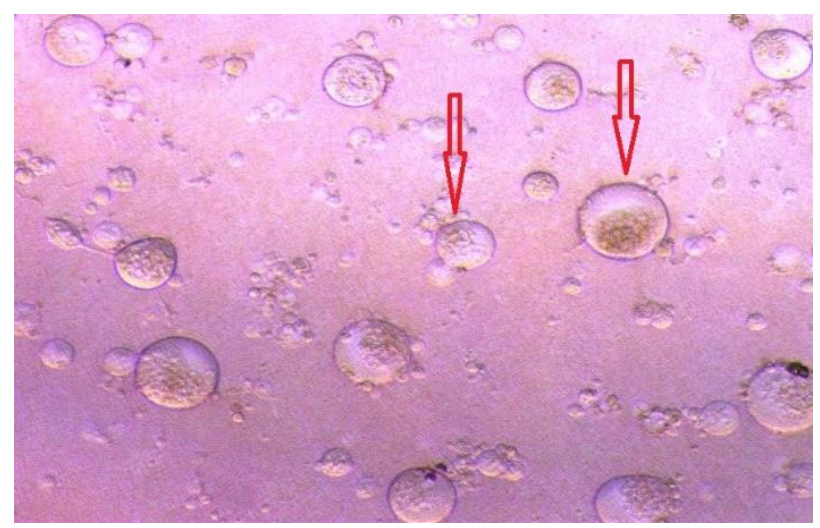

Fig. 2. CPE view of RSV in HEp-2 cells (Original).

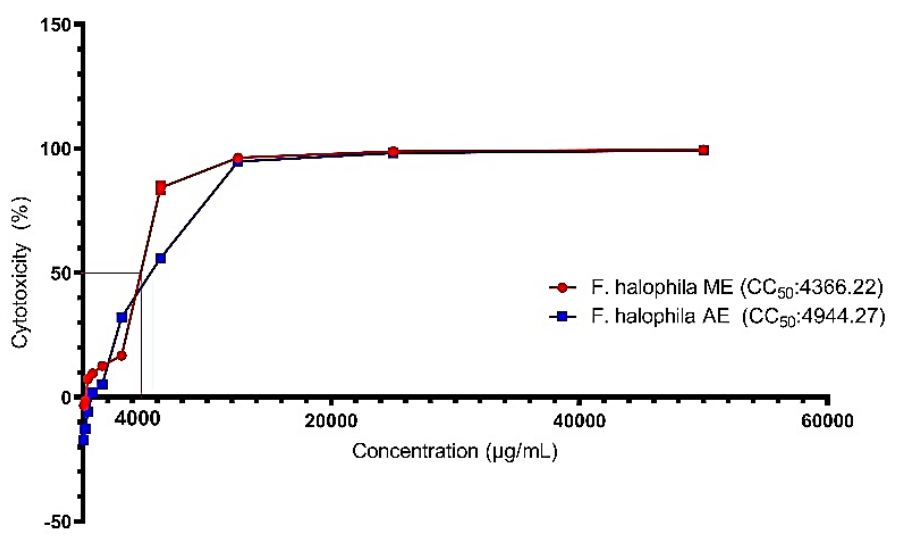

Fig. 3. Cytotoxicity of the extracts.

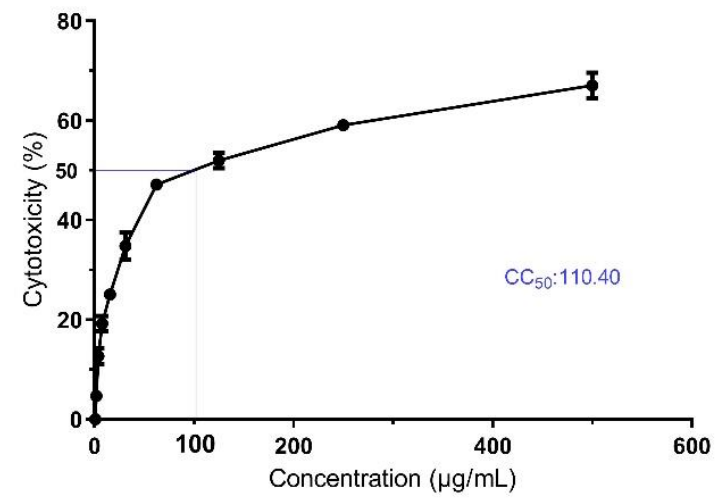

Fig. 4. Cytotoxicity of the ribavirin.

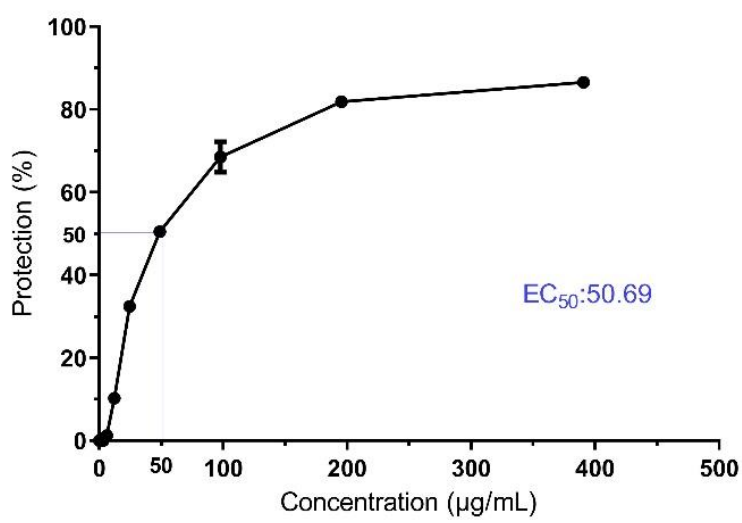

Fig. 5. Antiviral activity of the aqueous extract.

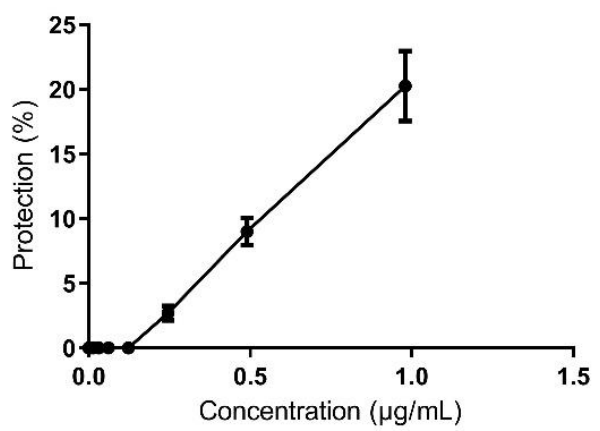

Fig. 6. Antiviral activity of ribavirin. 
Table 1. Cytotoxicity and antiviral activity of methanol and aqueous extracts of $F$. halophila and RBV.

\begin{tabular}{cccccc}
\hline \hline \multirow{2}{*}{ Plant species } & Extract type & $\begin{array}{c}\text { TNTCs } \\
(\mu \mathrm{g} / \mathrm{mL})\end{array}$ & $\begin{array}{c}\mathrm{CC}_{50} \\
(\mu \mathrm{g} / \mathrm{mL})\end{array}$ & $\begin{array}{c}\mathrm{EC}_{50} \\
(\mu \mathrm{g} / \mathrm{mL})\end{array}$ & SI \\
\cline { 3 - 6 } & Methanol & 195.313 & 4366.22 & - & - \\
\multirow{3}{*}{ Ferula halophila } & Aqueous & 390.625 & 4944.27 & 50.69 & 97.54 \\
& Ribavirin & 0.98 & 110.40 & 2.39 & 46.19 \\
\hline \hline
\end{tabular}

This is important for the reliability of an antiviral agent (Schinazi et al. 2009). Besides, Chattopadhyay et al. (2009) reported that if SI values are 10 or greater than 10 , antiviral results determined at or above this SI value may indicate that the extracts may have potential antiviral activity. Ferula species are rich in biologically active compounds, some of which are coumarins, sesquiterpenes, sesquiterpene coumarins, sesquiterpene lactones, and daucan esters (Zhou et al. 2017). It was reported in many studies on phytochemicals that these secondary metabolites and extracts obtained from Ferula species can show anti-fertility, antifungal, antiinflammatory, antispasmodic, antitumor, antiviral, antiulcerogenic, cancer chemopreventive, digestive enzyme inhibition and hypotensive effects (Iranshahy \& Iranshahi 2011). Ferula genus consists of 170 species in a wide region extending from Central Asia to the Mediterranean part (Mozaffarian 1996, Downie et al. 2000), and is represented in Turkey with 18 species of which 9 are endemic for the country (Davis 1972). Different parts of Ferula species are used in the treatment of various diseases such as neurological diseases, inflammations, dysentery, digestive system disorders, rheumatism, headache, arthritis and dizziness (Tamemoto et al. 2001). The anti-inflammatory, cytotoxicity and P-gp inhibitor, cancer chemo-preventive, antibacterial and antileishmanial activities of the components obtained from the genus Ferula are summarized (Nazari \& Iranshahi 2011).

Also, extracts, pure compounds and essential oils obtained from different Ferula species have been reported antiviral activities against DNA and RNA viruses such as influenza A (H1N1) (Lee et al. 2009), hepatitis B (Zhai et al. 2012), HSV-1 (Mohamed et al. 2006, Ghannadi et al. 2014, Duman 2016). Lee et al. (2009) isolated 11 sesquiterpene coumarins from $F$. assa-foetida extract, and these sesquiterpene coumarins were effective against influenza $\mathrm{A}(\mathrm{H} 1 \mathrm{~N} 1)$ virus at $\mathrm{EC}_{50}$ values ranging from $0.26-0.99 \mu \mathrm{g} / \mathrm{mL}$. This result is more effective than the traditional antiviral agent amantadine $\left(\mathrm{EC}_{50} 0.92 \mu \mathrm{g} / \mathrm{mL}\right)$ used against $\mathrm{H} 1 \mathrm{~N} 1$ virus.

The basic contents of essential oils obtained by hydrodistillation from dried roots of $F$. hormonis Boiss. were analysed by Gas Chromatography-Mass Spectroscopy (GC-MS) and the anti-HSV-1 activity of the essential oil was evaluated with the plaque inhibition test. The results showed that the plaque inhibition percentage of essential oil against HSV-1 was 81.4 (Mohamed et al. 2006).
In a study evaluating the anti-HSV-1 activities of sesquiterpene coumarins (badrakemin acetate, kellerin (2) and samarcandin diastereomer) isolated from the gum resin of F. assa-foetida, it has been shown that kellerin could significantly inhibit the cytopathic effects and reduce the viral titre of theHSV-1 DNA viral strain KOS at concentrations of 10,5 and $2.5 \mu \mathrm{g} / \mathrm{mL}$ (Ghannadi et al. 2014). Antiviral activity of the methanol and water extracts of $F$. halophila was investigated against HSV1(strain HF, ATCC VR-260) by the colorimetric XTT assay in vitro HSV-1/Vero cell systems by Duman (2016). According to his results, $\mathrm{EC}_{50}$ and SI values for methanol extract were $1035.29 \mu \mathrm{g} / \mathrm{mL}$ and 35.56, respectively, and $\mathrm{EC}_{50}$ and SI values for water extract were $264.45 \mu \mathrm{g} / \mathrm{mL}$ and 130.81 , respectively. Similarly, $\mathrm{EC}_{50}$ and SI of aqueous extract ( $\mathrm{EC}_{50}$ : 50.64, SI: 97) in the present study are higher than methanol extract. According to Duman (2016) and our results, we can say that aqueous extracts are more effective than methanol extracts. Several compounds, including glucuronic acid, galactose, arabinose, and rhamnose (Kapoor 1990), sulfurcontaining derivatives (Kajimoto et al. 1998), coumarins (Iranshahi et al. 2004), sesquiterpenes (Gonzalez \& Barrera 1995), sesquiterpene coumarins (Ahmed 1999, Ahmed et al. 2001), sesquiterpene lactones, and daucane esters are important in various biological activities of Ferula species. Among these compounds, sesquiterpene coumarins are very important because of their wide range and promising biological properties, particularly their antiviral properties. Indeed, it has been shown that sesquiterpene coumarins obtained from $F$. assa-foetida have significant antiviral activity against HSV-1 KOS strain (Ghannadi et al. 2014).

According to the current literature, there is only one study on the phytochemical profile of $F$. halophila (Zengin et al. 2018), and there are no studies on anti-RSV activity. Zengin et al. (2018) studied acetone, chloroform, and methanol extracts of $F$. halophila on diabetes $(\alpha-$ amylase, $\alpha$-glucosidase), cognitive functions [acetyl cholinesterase (AChE), butyrylcholinesterase (BChE)], inhibitor effects against hyperpigmentation (tyrosinase) related enzymes and mutagenic/antimutagenic activities. They also detected its phytochemical profiles by LCMS/MS (Liquid Chromatography-Mass/Mass Spectrophotometer). According to their results, total phenolic contents for acetone, methanol and chloroform extracts of $F$. halophila were found as 55.22, 48.06, andb20.66 mg GAE/g, respectively, while total flavonoid contents for the same extracts were $34.52,24.13$, and 8.61 
$\mathrm{mg} / \mathrm{g}$, respectively. Many phenolic agents, especially flavonoids, are known to have antiviral activity against different types of viruses, including RSV (Naithani et al. 2008, Li et al. 2014).

However, it was determined that $F$. halophila methanol extract did not have antiviral activity against RSV, whereas the aqueous extract of the same plant had significant antiviral activity. This may be due to the presence of the compound or compounds that are soluble in water, which are insoluble in the methanol extract.

\section{Conclusion}

In this study, anti-RSV activities of methanol and aqueous extracts of $F$. halophila were investigated, and aqueous extract exhibited the highest antiviral effect. To find the compound that causes antiviral activity, it is necessary to analyse the aqueous extract in the following steps and to renew the antiviral tests. In this way, the active substance or substances would be determined and they would be used as new antiviral drugs. However, the methanol extract did not show any antiviral effect. Due to

\section{References}

1. Ahmed, A.A. 1999. Sesquiterpene coumarins and sesquiterpenes from Ferula sinaica. Phytochemistry, 50: 109-112.

2. Ahmed, A.A., Abd El-Razek, M.H., Nassar, M.I., Izuma, S., Ohta, S. \& Hirata, T. 2001. Sesquiterpene coumarins from the roots of Ferula assa-foetida. Phytochemistry, 58: 1289-1295.

3. Andrighetti-Fröhmer, C.R., Antonio, R.V., GreczynskiPasa, T.B., Barardi, C.R.M. \& Simões, C.M.O. 2003. Cytotoxicity and potential antiviral evaluation of violacein produced by Chromobacterium violaceum. Memórias do Instituto Oswaldo Cruz, 98: 843-848.

4. Baytop, T. 1984. Türkiye'de Bitkilerle Tedavi. İstanbul Üniversitesi Eczacılık Fakültesi Yayınları No: 3255, İstanbul, $371 \mathrm{pp}$.

5. Chattopadhyay, D., Chawla-Sarkar, M., Chatterjee, T., Dey, R.S., Bag, P., Chakraborti, S. \& Khan, M.T.H. 2009. Recent advancements for the evaluation of antiviral activities of natural products. New Biotechnol, 25: 347-368.

6. Collins, P.L. \& Crowe, J.E. 2007. Respiratory syncytial virus and metapneumovirus. pp: 1601-1646. In: Knipe D.M., Howley P.M., Griffin D.E., Martin M.A., Lamb R.A., Roizman B., Straus S.E. (eds.). Fields Virology. Lippincott Williams \& Wilkins, Philadelphia, 2501 pp.

7. Collins, P.L. \& Melero, J.A. 2011. Progress in understanding and controlling respiratory syncytial virus: still crazy after all these years. Virus Research, 162: 80-99.

8. Davis, P.H. 1972. Flora of Turkey and the East Aegean Islands Vol: 4. Edinburgh University Press, Edinburgh, 657 pp.

9. Downie, S.R., Watson, M.F., Spalik, K. \& Katz-Downie D.S. 2000. Molecular systematics of old World 2. Apioideae (Apiaceae): relationships among some members of tribe Peucedaneae sensu lato, the placement of several the high toxicity of the methanol extract on HEp-2 cells, the use of lower concentrations in the antiviral test might have reduced the antiviral effect, or the antiviral compounds had not been completely dissolved in the methanol extract.

Ethics Committee Approval: Since it was a systematic review, its approval to the ethics committee was not required.

Author Contributions: Concept: H.H.D, R.D., Design: H.H.D, R.D., Execution: H.H.D, R.D., Material supplying: H.H.D, R.D., Data acquisition: H.H.D, R.D., Data analysis/interpretation: H.H.D, R.D., Manuscript writing: H.H.D, R.D., Critical revision: H.H.D, R.D.

Conflict of Interest: The authors have no conflicts of interest to declare.

Funding: This work was supported by Selçuk University, Scientific Research Projects Coordinating Office, Project Number: BAP/17401079.

island-endemic species, and resolution within the apioid superclade. Canadian Journal of Botany, 78: 506-528.

10. Drude, O. 1898. Ferula L. In A. Engler (Ed.), Die natürlichen Pflanzenfamilien, Wilhelm Engelmann, Leipzig, Vol. 3(8): 228-232.

11. Dudas, R.A. \& Karron R.A. 1998. Respiratory syncytial virus vaccines. Clinical Microbiology Reviews, 11(3): 430439.

12. Duman, R. 2016. Antiviral activity of Ferula halophila Peşmen against herpes simplex virus type 1 (HSV-1). International Journal of Scientific and Technological Research, 2(4): 1-9.

13. Durbin, A.P \& Karron, R.A. 2003. Progress in the development of respiratory syncytial virus and parainfluenza virus vaccines. Clinical Infectious Diseases, 37(12): 1668-1677.

14. Falsey, A.R. \& Walsh, E.E. 2000. Respiratory syncytial virus infection in adults. Clinical Microbiology Reviews, 13(3): $371-384$

15. Ghannadi, A., Fattahian, K., Shokoohinia, Y., Behbahani, M. \& Shahnoush, A. 2014. Anti-viral evaluation of sesquiterpene coumarins from Ferula assa-foetida against HSV-1. Iranian Journal of Pharmaceutical Research, 12(2): 523-530.

16. Gliszczyńska, A. \& Brodelius, P.E. 2012. Sesquiterpene coumarins. Phytochemistry, 11(1): 77-96.

17. Gonzalez, A.G. \& Barrera, J.B. 1995. Chemistry and the sources of mono- and bicyclic sesquiterpenes from Ferula species. Progress in the Chemistry of Organic Natural Products, 64: 1-92.

18. Hall, C.B., Weinberg, G.A., Iwane, M.K., Blumkin, A.K., Edwards, K.M., Staat, M.A., Auinger, P., Griffin, M.R., Poehling, K.A., Erdman, D., Grijalva, C.G., Zhu, Y. \& 
Szilagyi, P. 2009. The burden of respiratory syncytial virus in young children. The New England Journal of Medicine, 360(6): 588-598.

19. Ho, W.S., Xue, J.Y., Sun, S.S., Ooi, V.E. \& Li, Y.L. 2010. Antiviral activity of daphnoretin isolated from Wikstroemia indica. Phytotherapy Research, 24(5): 657-661.

20. Iranshahi, M., Amin, G. \& Shafiee, A. 2004. A new coumarin from Ferula persica. Pharmaceutical Biology, 42: $440-442$

21. Iranshahy, M. \& Iranshahi, M. 2011. Traditional uses, phytochemistry and pharmacology of Asafoetida (Ferula assa-foetida oleo-gum-resin)-A review. Journal of Ethnopharmacology, 134(1): 1-10.

22. Kaerber, G. 1964. Diagnostic procedures for virus and rickettsial disease. Public Health Association, 3: 48-50.

23. Kajimoto, T., Yahiro, K. \& Nohara, T. 1998. Sesquiterpenoid and disulphide derivatives from Ferula assa-foetida. Phytochemistry, 28: 1761-1763.

24. Kapoor, L.D. 1990. Handbook of Ayurvedic Medicinal Plants. CRC Press, Boca Raton, FL, 424 pp.

25. Kneyber, M.C.J., Mou, H.A. \& Groot, R.D. 2000. Treatment and prevention of respiratory syncytial virus infection. European Journal of Paediatrics, 159: 339-411.

26. Lambert, L., Sagfors, A.M., Openshaw, P.J. \& Culley, F.J. 2014. Immunity to RSV in early-life. Frontiers in Immunology, 5: 466.

27. Lee, C.L., Chiang, L.C., Cheng, L.H., Liaw, C.C., ElRazek, M.H.A., Chang, F.R. \& Wu, Y.C. 2009. Influenza A (H1N1) antiviral and cytotoxic agents from Ferula assa-foetida. Journal of Natural Products, 72: 15681572.

28. Li, Y., Ooi, L.S., Wang, H., But, P.P. \& Ooi, V.E. 2004. Antiviral activities of medicinal herbs traditionally used in southern mainland China. Phytotherapy Research, 18: 718722.

29. Lindsay, B., Helen, G., Michael, D. \& Ultan, F.P. 2015. Respiratory syncytial virus, an ongoing medical dilemma: an expert commentary on respiratory syncytial virus prophylactic and therapeutic pharmaceuticals currently in clinical trials. Influenza and other Respiratory Viruses, 9(4): $169-178$

30. Mohamed, S.M., Ibrahim, N.A., Ali, M.A. \& Faraid, M.A. 2006. Chemical composition, antiviral and antimicrobial activities of the essential oils of Ferula hormonis, Plectranthus coleoides and Magnolia grandiflora. Planta Medica, 72: 113.

31. Mozaffarian, V. 1996. A Dictionary of Iranian Plant Names. Farhang Moaser Publications, Tahran, 70 pp.

32. Nair, H., Nokes, D.J., Gessner, B.D., Dherani, M., Madhi, S.A., Singleton, R.J., O'Brien, K.L., Roca, A., Wright, P.F., Bruce, N., Chandran, A., Theodoratou, E., Sutanto, A., Sedyaningsih, E.R., Ngama, M., Munywoki, P.K., Kartasasmita, C., Simões, E.A., Rudan, I., Weber, M.W. \&
Campbell, H. 2010. Global burden of acute lower respiratory infections due to respiratory syncytial virus in young children: a systematic review and meta-analysis. Lancet, 375 (9725): 1545-1555.

33. Naithani, R., Huma, L.C., Holland, L.E., Shukla, D., Mccormick, D.L., Mehta, R.G. \& Moriarty, R.M. 2008. Antiviral activity of phytochemicals: A comprehensive review. Mini-Reviews in Medicinal Chemistry, 8: 11061133.

34. Nazari, Z.E. \& Iranshahi, M. 2011. Biologically active sesquiterpene coumarins from Ferula species. Phytotherapy Research, 25: 315-323.

35. Pelaez, A., Lyon, G.M., Force, S.D., Ramirez, A.M., Neujahr, D.C., Foster, M., Naik, P.M., Gal, A.A., Mitchell, P.O. \& Lawrence E.C. 2009. Efficacy of oral ribavirin in lung transplant patients with respiratory syncytial virus lower respiratory tract infection. The Journal of Heart and Lung Transplantation, 28(1): 67-71.

36. Samsam Shariat, S.H. \& Moattar F. 1990. Medicinal Plants and Natural Products, Mashal Publications, Isfahan. p. 431-433.

37. Schinazi, R.F., Coats, S.J., Bassit, L.C., Lennerstrand, J., Nettles, J.H. \& Hurwitz S.J. 2009. Approaches for the development of antiviral compounds: the case of hepatitis C virus. Handbook of Experimental Pharmacology, 189: 25-51.

38. Shoemaker, M., Cohen, I. \& Campbell M. 2004. Reduction of MTT by aqueous herbal extracts in the absence of cells. Journal of Ethnopharmacology, 93(2-3): 381-384.

39. Tamemoto, K., Takaishi, Y., Chen, B., Kawazoe, K., Shibata, H., Higuti, T., Honda, G., Ito, M., Takeda, Y., Kodzhimatov, O.K. \& Ashurmetov, O. 2001. Sesquiterpenoids from the fruits of Ferula kuhistanica and antibacterial activity of the constituents of $F$. kuhistanica. Phytochemistry, 58: 763-767.

40. Varga, S.M. \& Braciale, T.J. 2013. The adaptive immune response to respiratory syncytial virus. Current Topics in Microbiology and Immunology, 372: 155-171.

41. Zengin, G., Uysal, A., Diuzheva, A., Gunes, E., Jekő, J., Cziáky, Z., Picot-Allain, C.M.N. \& Mahomoodally, M.F. 2018. Characterization of phytochemical components of Ferula halophila extracts using HPLC-MS/MS and their pharmacological potentials: a multi-functional insight. Journal of Pharmaceutical and Biomedical Analysis, 160: 374-382.

42. Zhai, L.L., Liu, T., Xie, H.Q., Xie, Y.H. \& Mu, Q. 2012. Inhibition effects on Hepatitis B virus replication by hydrophobic extracts from Ferula ferulaeoides (Steud.) Korov. Journal of Medicinal Plants Research, 6(8): 14861488.

43. Zhou, Y., Xin, F., Zhang, G., Qu, H., Yang, D. \& Han, X. 2017. Recent advances on bioactive constituents in Ferula. Drug Development Research 78(7): 321-331. 